\title{
Conjunção de conteúdos do projeto Células Cênicas com o ambiente Plataforma Virtual para Pensar, no contexto do I Encontro sobre Decolonialidade e Ciência da Informação: Veredas Dialógicas
}

\author{
Conjunction of contents of the Células Cênicas Project \\ with the Virtual Platform for Thinking environment, in the \\ context of the 1st Meeting on Decoloniality and \\ Information Science: Dialogic Paths
}

Marco Donizete Paulino da Silva a,* (D)

Nádia Regina Stevanato ${ }^{b}$

\begin{abstract}
RESUMO: relata o processo de construção, produção e execução da obra teatral, em formato audiovisual Células Cênicas, trabalho colaborativo que tem em seu bojo discussões sobre questões sociais, culturais e éticas do momento contemporâneo. Busca-se articular a proposta original dessa produção artística com os interesses de discussão do I Encontro sobre Decolonialidade e Ciência da Informação: Veredas Dialógicas, intercalando-se unidades textuais e audiovisuais da obra, interpretações hermenêuticas de sua proposição cênica e dramatúrgica e os elementos tidos como decoloniais. Aufere-se como resultante da experiência artística a projeção de uma leitura provocadora para que o leitor possa considerar a argumentação e os efeitos da exposição audiovisual.
\end{abstract}

Palavras-chave: Decolonialidade; Representações Sociais; Informação; Conhecimento.

ABSTRACT: reports the process of construction, production and execution of the theatrical work, in audiovisual format Células Cênicas, a collaborative work that has within it discussions about social, cultural and ethical issues of the contemporary moment. It seeks to articulate the original proposal of this artistic production with the interests of discussion of the 1st Meeting on Decoloniality and Information Science: Dialogic Paths, interspersing textual and audiovisual units of the work, hermeneutical interpretations of its scenic and dramaturgical proposition and the elements considered as decolonial. As a result of the artistic experience, the projection of a provocative reading is confirmed, so that the reader can consider the arguments and the effects of the audiovisual exhibition.

Keywords: Decoloniality; Social Representations; Information; Knowledge.

\footnotetext{
a Centro Universitário Claretiano, Batatais, SP, Brasil.

b Secretaria da Educação do Estado de São Paulo, Escola Estadual Ary Pinto das Neves, São Carlos, SP, Brasil.

* Correspondência para/Correspondence to: Marco Donizete Paulino da Silva. E-mail: marco_donizete@yahoo.com.br.
}

Recebido em/Received: 28/06/2021; Aprovado em/Approved: 05/10/2021.

Artigo publicado em acesso aberto sob licença CC BY 4.0 Internacional ()(i) 


\section{À GUISA DE INTRODUÇÃO}

Esse trabalho descreve o processo de elaboração do projeto Células Cênicas- peça teatral escrita por Marco Madeira, Nádia Stevanato e Doni Silva, realizada de forma colaborativa e em formato audiovisual, de abril a outubro de 2019 -, composto de dez vídeos curtos, inseridos no painel Plataformas Virtuais para Pensar, do Evento I Encontro Decolonialidade e Ciência da Informação.

A base temática da obra busca discutir a relação do ser humano com a informação e o conhecimento no contexto sociopolítico e cultural do Brasil e do mundo contemporâneo.

Ainda que questão decolonial não seja abordada explicitamente nos discursos proferidos pelos atores (agentes-intérpretes), a partir de suas posições-funções no mundo, é expressa (de forma mais direta) pela poesia de Doni Silva (em formato aproximado da poesia de cordel), especificamente nas falas ditas por Paulo Borges (representando uma voz interna dos personagens, sendo ouvida e respondida no final de cada célula - a começar pela Célula 1) (Figura 1).

Ou, na Célula 2: Fala 1b em que a relação entre mercado e explorados é expressa no diálogo entre orador - Paulo - e proclamante - Hélio Pajeú: “Orador: Senhor mercantilista./Proclamante: Pagai-nos os dividendos que lhe rendemos!” (CÉLULA 2, 2020, $7^{\prime} 46^{\prime \prime}$ )

Ou ainda, no trecho em que se mescla invocação, discurso religioso, prosa poética e neologismos:

Fie e teça o conhecimento para o centro de nossos corações, os cordões trazidos de nossas terras e quimeras, vindos e constituídos de todos os cantos, inclusive, daqueles nascidos do chão da floresta, palco onde a ciência da simbiose é pura bioquímica encenada, onde sabimentos nativos caminham ao encontro de desconhecimentos prévios, recontando trajetórias silenciadas, pondo unguentos nas cicatrizes deixadas pelas tragédias de nossa desconexão ameríndia. (CÉLULA 4, 2020, 1'27") 
Figura 1. Voz da consciência de cada átomo-personagem em cada célula.

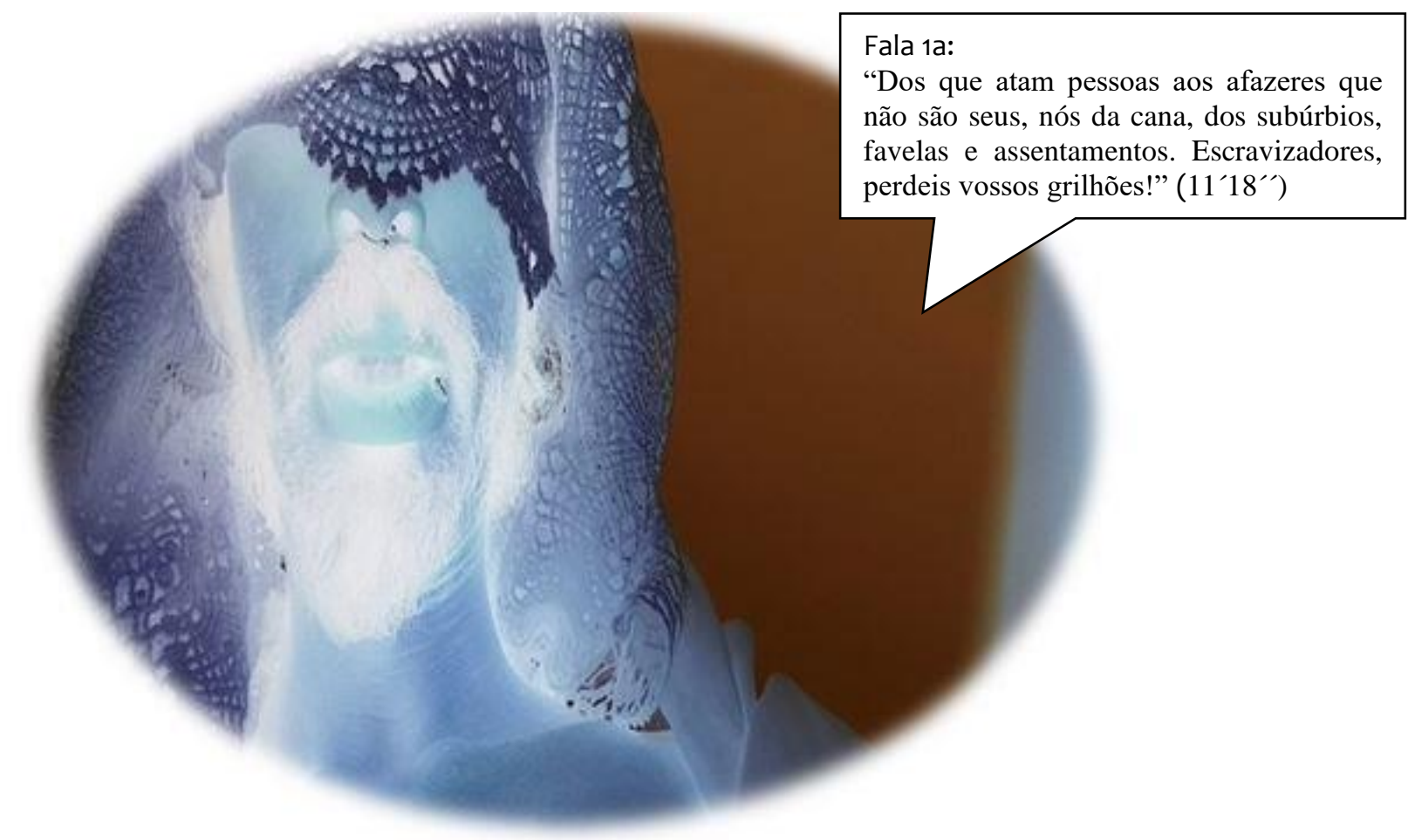

Nota: Imagem do vídeo completo da Célula 1. Duração de 12'46”. Disponível em: https://www.youtube.com/watch?v=abGJpgKTjvQ .

Estas, dentre algumas outras falas, são abordagens que criticam a herança colonial nas áreas que discute (conhecimento, informação, educação, linguagem), cabendo ainda, pela perspectiva da Linguagem, assumir essa discussão pela condição de uso gramatical do pronome neutro, em palavras como "mesme", por exemplo.

De forma transversal, tais abordagens emergiram no processo de realização da encenação, sobretudo pela natureza dramatúrgica da obra: alicerçada na consideração de texto e fala serem disponibilizados aos agentes/intérpretes pela liberdade de reformulação textual-performática de cada cena, horizontalizando a relação de trabalho entre dramaturgos-encenadores e agentes performáticos resultantes do processo interpretativo.

Formalmente, o trabalho se organizou em unidades-subtítulos, pela seguinte condição temática (divisão que será respeitada na descrição de eixos-orientação do processo de análise da obra): 1) Abertura; 2) Produção e uso dos temas a partir de suas funções em exercício, e das buscas de experienciação suscitadas em níveis gradativos de informação, conhecimento e saber; e, 3) Finalização.

O embasamento teórico do projeto se deu pela ideia de integração de discursos a partir de personas (máscara social), tendo-se por intenção conjugar texto dramatúrgico e identidade do agente performático (razão pela qual, antes de cada monólogo, o 
intérprete se localiza enquanto sujeito histórico, reconhecendo-se como porta-voz de sua própria definição na situação cênica expressa).

Tal mecanismo derivou da consideração de duas teorias:

- De Representação Social do Sujeito: formulada por Irving Goffman (2002), a partir do campo da Psicologia, em meados do século passado; e,

- De performance do Ator Natural: nascida no campo do Cinema Documentário, formulada por Sérgio Santeiro (1978), no final de 1970.

No contexto de Células Cênicas, tanto a função intérprete (classe) quanto sua alocação histórica (representação) coadunam uma junção entre a representação desse sujeito a partir de sua persona e sua representação, relacionando essa articulação em relação ao que se diz do ponto de vista de uma linguagem formal e simbólica expressa pelo registro audiovisual.

Nessa perspectiva, a sintaxe audiovisual funcionaria como moldura-forma, dispositivo de registro da cena que resulta - tendo por base o posicionamento da câmera fixa enfatiza o que se diz, ou seja, o texto performatizado, do que decorre, nesse sentido, ênfase no discurso verbal tanto pela ótica simbólica dos termos quanto pela atmosfera perseguida a partir dos sons ambientes utilizados como indicadores de uma paisagem sonora enraizada nos ambientes sociais que os sustentam.

\section{EVOLUÇÃO TEMÁTICA}

Na realização do trabalho Células Cênicas, um procedimento padrão adotado foi o de dividir o elemento estrutural da narrativa em eixos temáticos que derivavam tanto objetivos de condução dramatúrgica quanto de questionamento de situaçõesproblema na ordem social e política.

Como já informado, a identidade de cada intérprete também trouxe - por meio da troca entre dramaturgistas-diretores e intérpretes - aquisições ou reforço dos conteúdos, ou seja, maior imbricação entre quem são e como se autodenominam tais agentes (informação adicional que enfatiza trechos ou frases do texto interpretado reelaborando e ampliando tais possibilidades).

Visando maior clareza sistemática desse trabalho e melhor visualização das etapas que o compuseram, antes de cada incursão argumentativa sobre a célula e seu tema, os dados à ela referentes (identificação da cena, do intérprete/personagem/função, sua fala e momento (tempo) de registro no objeto audiovisual) serão apresentados por elementos gráficos que sintetizam tais condições.

Pelos processos de seleção e apresentação dos termos em pauta, aqui em análise, objetivou-se providenciar o enfoque argumentativo acerca dos teores representativos de coadunação entre persona, ação de representação, dispositivo utilizado na ordem 
imagética (quadro fixo ou efeito de corte) e sonora (ambientação) em relação ao tema decolonial proposto pelo ambiente Plataforma Virtual para Pensar.

\begin{abstract}
Abertura
Célula 0 - Pró-logando-se

A Célula 0, denominada Pró-logando-se, tem como agente-intéprete o ator Marco Madeira - com atuação formal como bibliotecário, professor, acadêmico, informalmente atuante como agente cultural, ator, diretor e dramaturgo de teatro. A cena representa o nascimento do personagem "A Criatura", que propõe o início de uma jornada de investigação (por meio de divisões simbólicas de si em átomospersonagens) sobre o processo de construção de uma consciência ética, a partir da abordagem desse processo em gradações que se conformam em níveis informacionais, de conhecimento e sabedoria, tendo por questões as cismas que a angustiam, e a impelem à busca de respostas.
\end{abstract}

Enquanto dispositivos ativados na cena, têm-se como constante o enquadramento sem movimentos de câmera (padrão adotado na maioria das células).

De início vemos Marco dizendo a fala introdutória mantendo uma relação performática do corpo em relação a delimitação do espaço, seus gestos e contornos expressivos são contidos no enquadramento e pelo ótica do que, esteticamente, desenha os movimentos, enfatizados pelo fundo negro, dando a impressão de "dissolução" dos contornos exatos da Criatura, toda vestida de preto, barba messiânica e faixa vermelha encobrindo a mão esquerda.

A primeira frase, tendo-se por ambientação sonora uma chuva carregada de trovões e sem raios (induzindo a ideia de um espaço sem comunicação com o externo), é dirigida para o alto (ao Criador) e descreve a lembrança que ela, Criatura, tem de seu nascimento: "Também vi um olhar sobre tudo que me acontecia - eu, sua cria, ele, quem me trouxe ao mundo. Também vi nos olhos dele toda maravilha e todo o horror, a fascinação e o temor do passo dado. Sou sua criatura".

Observa-se, nesse contexto e formatação, o esboço dos ditames pelos quais a obra se direcionará no transcorrer das cenas subsequentes: critério de plasticidade (poucas informações cenográficas), tom da linguagem adotada (vernacular rebuscada), enquadramento limitado, simbolismo mitológico como recorrência da referência simbólica do conteúdo.

Segue-se uma representação gráfica dos elementos que compõe a célula, seguindo-se as diretrizes metodológicas descritas na introdução. 
Figura 2. A Criatura em um momento de seu solilóquio.

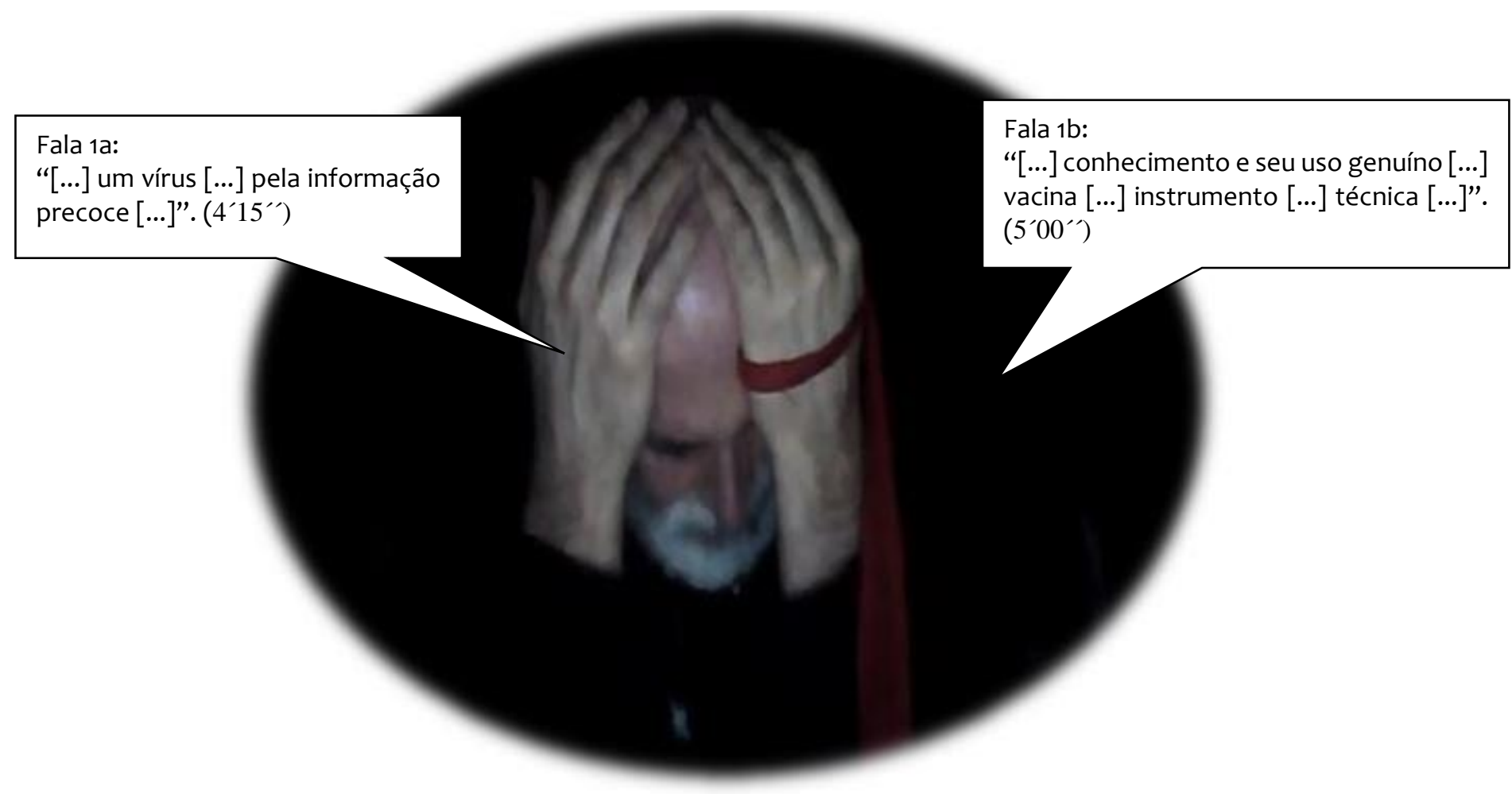

Nota: vídeo completo com duração de 11'43". Disponível em:

https://www.youtube.com/watch?v=aFwQh_ymql4\&t=2515.

Em continuidade a esse pensamento, na Fala 1a, em que se é revelado a parte de dentro de um manto (até agora aparentemente preto), que possui uma estampa de pequenos sinais brancos, simbolicamente relacionando as pequenas estampas ao termo vírus (destacado no texto do Quadro 1) e do termo Informação precoce (idem).

Nessa perspectiva, a informação - assim como outros conceitos abordados no decorrer da obra - é o primeiro signo trazido, e como uma dinâmica virulenta, pela leitura da personagem.

Na Fala 1b, como evolução temática, se insere a ideia de Conhecimento como instrumento de reversão dos problemas causados pelo uso de uma "informação precoce". Atribuindo-se, metaforicamente, sentidos simbólicos do Conhecimento como vacina/instrumento conotado pelos signos "seringa" e "injeção", potencializando a busca que se inicia tanto pela presunção de "salvação" quanto uma possível "prevenção" ao sentimento de decadência evidenciado ao longo da exposição. 
Figura 3. A Criatura em outro momento de seu solilóquio.

Fala 2a:

"[...] em meus membros costurados $[\ldots]$ ganância $[\ldots]$ arrogância $[\ldots]$ desprezo [...] necrose de valores éticos [...]". $(6 ' 08$ '')

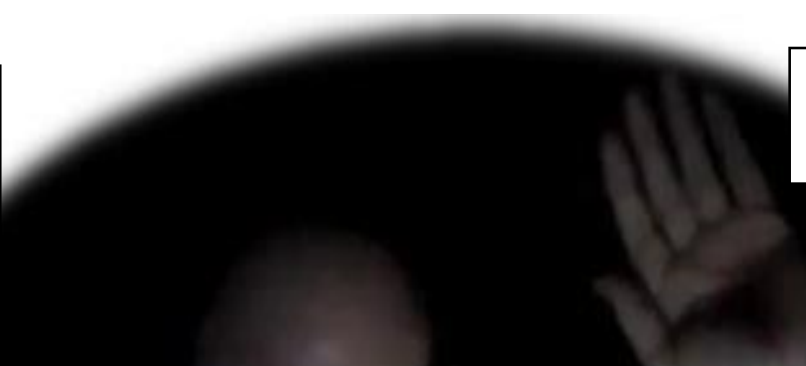

Fala 2b:

“[...] Fake News Diary [...]". (7'06')

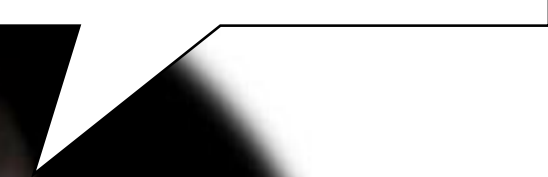

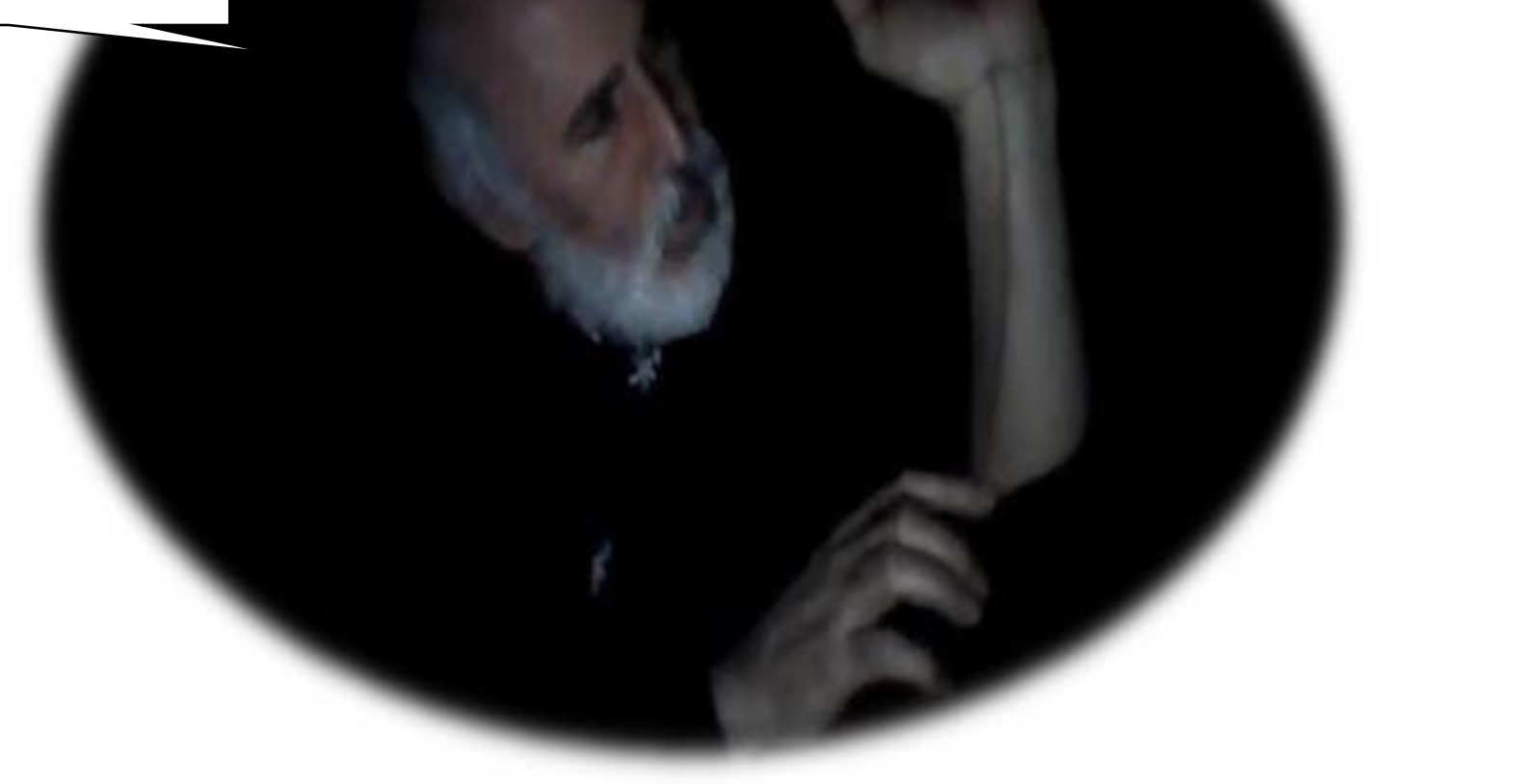

Nota: vídeo completo com duração de 11'43". Disponível em:

https://www.youtube.com/watch?v=aFwQh_ymql4\&t=2515.

Esse sentido de decadência se evidencia na Fala 2a, pela qual se traça um paralelo entre a "composição" híbrida da Criatura - composta por meio de "membros costurados" (momento em que ela desenrola a faixa vermelha e apresenta tanto uma chaga na palma da mão quanto o que parece ser traços de uma costura de pele ao longo de todo o antebraço) -, e sua decomposição interna, expressa pelos termos "Ganância", "Arrogância" (alicerces dessa incapacidade de ser humana) como valores contaminados pelo "Desprezo" e pela perda do senso ético, ou seja, "necrose de valores éticos".

O mesmo fator é enfatizado na Fala $2 b$, em que, dando continuidade ao tema, mas "quebrando-se" o que se convenciona chamar de "quarta parede" (reconhecimento de uma audiência cênica pela personagem), a Criatura dirige-se diretamente ao espectador, incluindo-o como um dos indiferentes aos desastres listados, mas condicionando tais desastres ao alastramento cotidiano de "Fake News Diary". Essa relação com o espectador se manterá até o fim do vídeo.

Por último, como encerramento da cena, dois momentos parecem importantes: 
- momento em que, pelo uso de um espelho, a personagem simula, antecipadamente, seu desdobramento em vários outros agentes - denominados "átomos"; e,

- como elemento de ligação e fechamento da cena, a personagem é "engolida" pelo manto que utilizou durante a performance (com desenhos "virais") e tudo some, ficando apenas o blackout provocado pela ação.

\section{Célula 1 - Ritualizando-se}

Nessa célula o átomo-personagem abre o trajeto de discussão proposto pela Criatura, apresentando e descrevendo o cenário contemporâneo de perda dos sentidos éticos em torno da relação entre humano e humano, humano e máquina, e humano e natureza. Observa-se que o tom hierático - que contamina a maioria das cenas subsequentes -, teve sua base no caráter trágico de Édipo Rei, clássico grego de Sófocles, pelo qual essa cena teve sua gênese inspiradora.

A perspectiva real de Andrógine Zago, artista visual, designer e performer, é de uma intérprete/"sacerdotise"" que, ritualisticamente, prepara a arena simbólica de embates.

Sua apresentação de si "mesme" (Fala 1a) a localiza entre esferas fluidas, mas ainda e talvez, por isso mesmo - auto intitulada "entidade não binária". Dessa forma, o mito de Hermes, esse mensageiro entre mundos, funciona como inauguração da saga que descortina tanto elementos concretos (estruturas sociais, por exemplo) quanto abstratos e etéreos (como estados psicológicos identitários).

A cena se inicia com a tela preta e a voz da criatura (dispositivo utilizado em todas as cenas subsequentes).

A seguir, vemos as mãos de atriz abrir a "cortina" preta para entrar "em cena". Ao fundo, o som murmurante que a platéia costuma fazer enquanto espera a peça começar.

Andrógine se apresenta:

Meu nome é Andrógine, divindade não binária do não pertencer. Sim, eu sou artista, é claro. E, como tal, eu sinto fome, fúria, tesão, impulsos incendiários. Por escolha ou destino, me faço também refúgio das identidades nulas, ambíguas, fluidas, acumulativas ou ainda desconhecidas. (CÉLULA 1, 2020)

\footnotetext{
${ }^{1}$ A forma de tratamento nessa subseção será utilizada, buscando coerência com seu conteúdo, na mesma adequação formulada pela personagem (traço lingüístico solicitado por ela própria). Essa adequação configurou-se como opção política no uso da linguagem, defendendo seu autoreconhecimento não binário.
} 
Enquanto dispositivo cênico, Andrógine faz uso de uma cadeira giratória, mantendose, no mesmo padrão narrativo adotado na célula anterior, com exceção de algumas edições no final da cena, momento em que a voz de uma simbólica consciência superior dialoga com os personagens por meio de versos similares ao cordel (sempre presente no final das células).

De forma específica, enfatizam-se duas falas de Andrógine.

Figura 4. Átomo-personagem 1, ritualizando a abertura do trajeto.

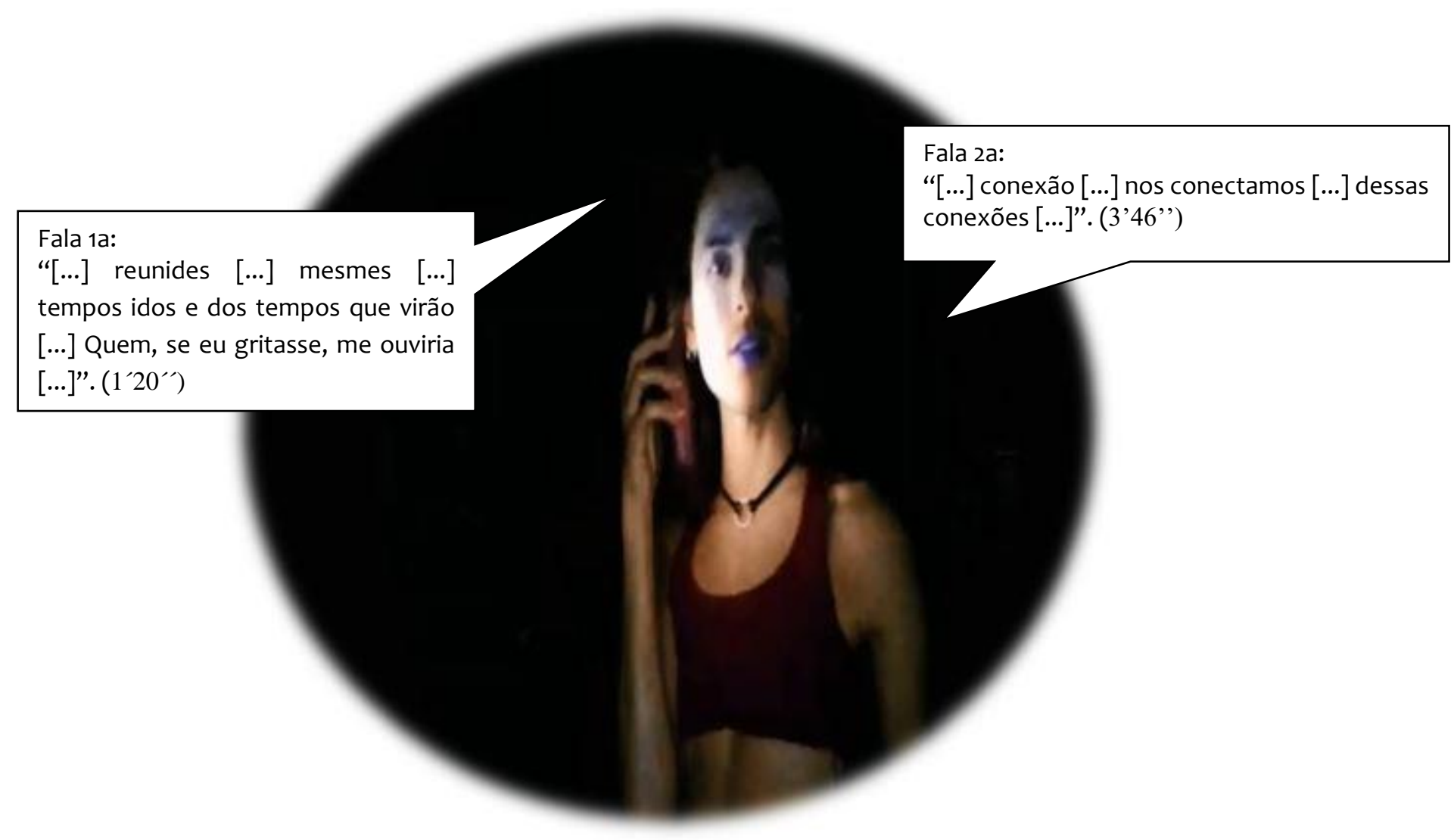

Nota: vídeo completo com duração de 12'46". disponível em:

https://www.youtube.com/watch?v=abGJpgKTjvQ .

A fala 1a abarca uma sequência de termos referidos a si "mesme" que, após uma lista de funções questionadoras das convenções, Andrógine determina como um espaço atemporal de apreciação do trajeto, pela combinação dos termos "tempos idos e dos tempos que virão", conclamando -, a seguir, a identificação daqueles que estariam dispostos a ouvir seu chamado,

$\mathrm{Na}$ Fala 2a, a atriz, de posse de seu celular (artefato que entroniza o aspecto conectivo das redes tecnológicas no contexto, comunicacional-social), posiciona-se a respeito da 
responsabilidade do individuo no ato de conexão - observa-se o aparecimento constante dos termos "conexões" e "conectamos" na fala.

Uma cisma que se considera emergir dessas considerações de Andrógine é: o quanto de narcisístico se sobrepõe à ação do indivíduo em detrimento de sua "potência de transformação" do mundo.

\section{Produção e uso dos temas: informação, conhecimento e saber}

Enfatiza-se que todas as subseções dessa seção foram consideradas como pertencentes a um mesmo processo de "desintegração transcendente" da Criatura que, no processo de maturação de suas inquirições iniciais, consagradas pela abertura ritual de Andrógine Zago, se divide em átomos proclamantes, personificados pelos agentes em ação cênica e social.

Célula 2 - Consumindo-se

Essa é a primeira de duas abordagens da questão Informacional, considerada, respectivamente, a partir de seus processos de produção e consumo.

A primeira imagem da cena é o contorno de um homem à meia luz. Ouve-se, ao fundo, ruídos de uma batalha - tiros, bombardeio. Vemos primeiramente sua sombra, e depois o corpo do ator em relação periódica de trocas contínuas entre as condições de comandante e comandado da ação.

Em sua primeira fala o ator, bailarino e acadêmico, Hélio Pajeú, apresenta-se como nordestino, complementando a seguir: "Meu lugar é o mundo todo e minha função no mundo é ser gente.", o que se concebe como a expressão da consciência de uma liberdade de pertencimento e pronunciamento do ser em sua humanidade.

Em sua cena, Hélio, enquanto átomo-personagem que vivencia os efeitos do excesso à exposição da informação, observa-se pela sensação de dissolução de si mesmo frente ao consumo exacerbado promovido pela disponibilização de objetos virtuais e não virtuais. 
Figura 5. Átomo-personagem 2, na fronteira de guerrilha.

Fala 1a:

“[...] profusão de desinformação [...] nesse embate midiático [...]". (2’11"')

Nota: vídeo completo com duração de 9'23". Disponível em:

https://www.youtube.com/watch?v=1/h_HPF_MZU.

A Fala 1a delibera sobre esse conflito entre as opções de escolha entre a multiplicidade de proposições de realidade sobre o mundo.

O trecho em que se destacam tais conflitos é observado, sinteticamente, pelo uso das expressões "profusão de desinformação" e "embate midiático".

Outros momentos salientam o grau de insatisfação ou deterioração do personagem, que, em nível imagético, relaciona acontecimentos catastróficos com uma possível representação dos mesmos (por exemplo, pela menção às bombas de Hiroshima e Nagasaki em combinação com a irradiação crescente da luz - representação imagética (estilizada) da explosão atômica).

\section{Célula 3-Re-produzindo-se:}

Compondo-se como fechamento do tema Informacional (pela condição da Informação ser caracterizada como produto de uma ordem sócio-industrial), a célula tem os som ambiente como metáfora, compondo-se pelos ruídos resultantes das operações de máquinas em uma fábrica.

Bruno Garbuio, ator, palhaço e licenciado em Filosofia, apresenta-se, declarando: "Meu nome é Bruno, meu lugar é São Carlos e a minha função é ser pedra no sapato”. A partir 
dessa circunstancialização o átomo-personagem exercita a função cênica de produção (do ponto de vista operacional, não decisório) da Informação.

Bruno circunscreve sua atuação por um viés distanciado, enfatizando a função catalisadora do personagem, guiada ora por realidades concretas, ora abstratas, nem sempre honestas, mas sempre impactantes no processo de informar por meio de manchetes jornalísticas.

Figura 6. Átomo-personagem 3, no domínio da produção.

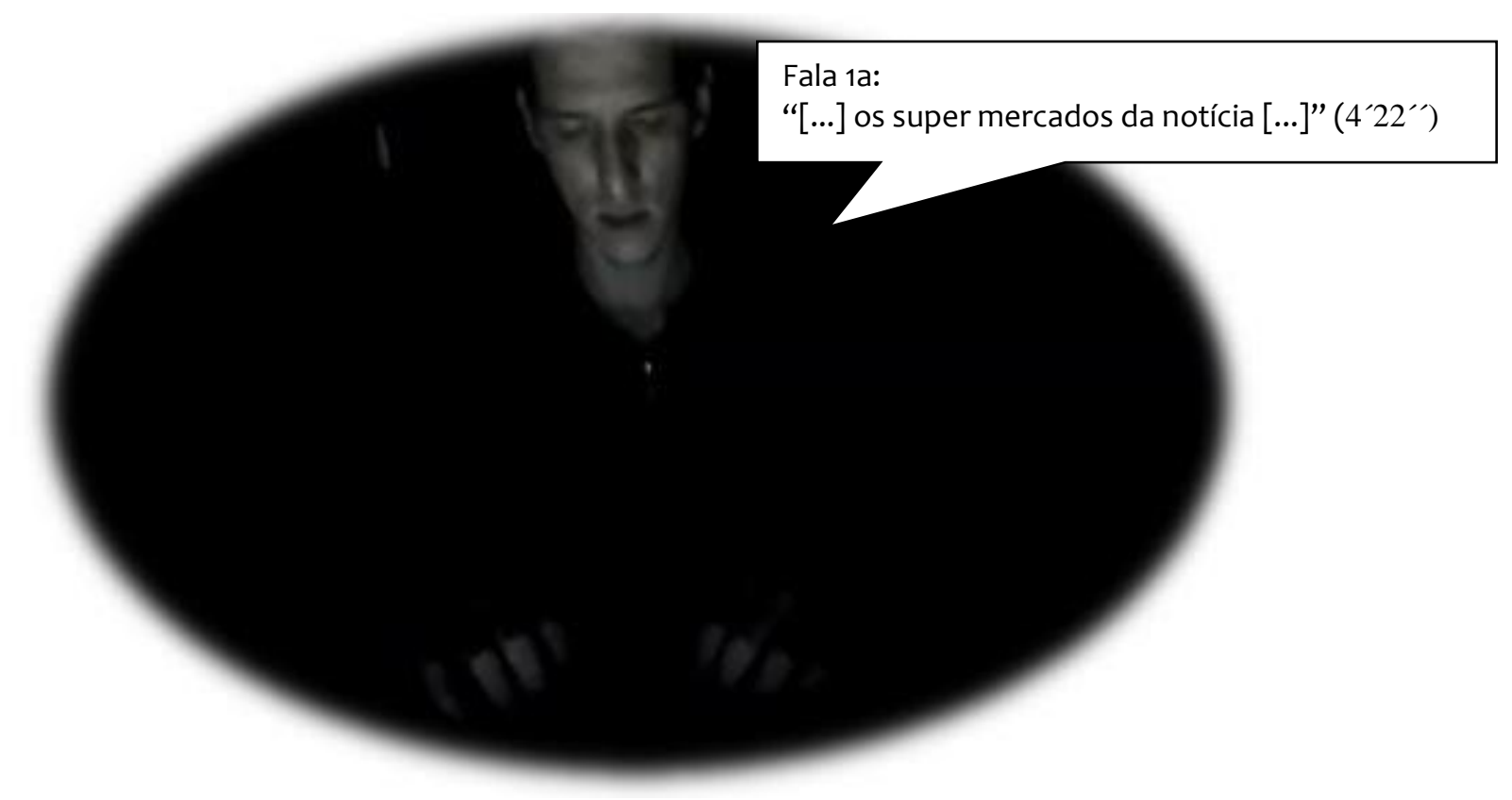

Nota: vídeo completo com duração de 8'11". Disponível em:

https://www.youtube.com/watch?v=fqvErE fEio\&t=56s .

A mise em scene é estabelecida com elementos comportamentais do universo de uma redação de jornal, pelos quais se observa que o personagem fala em voz alta o texto que, concomitantemente produz, enquanto digita no teclado de seu computador.

Essa situação de registro da performance é salientada em pela Fala 1a, quando o ator conduz a câmera que o está filmando, enquadrando o monitor pelo qual se visualiza a imagem do repórter, que aparece em uma gravação de si mesmo.

Na gravação, o termo "super mercado de notícias" resume a série de manchetes anunciadas pela voz de Bruno, qualificando cada título pela ordem, aparentemente, sensacionalista, carregadas de uma intenção estratégica em situar a notícia como um agregado de construções gramaticais sem sentido, ou, quando muito, de sentido hiper estilizado, absorvendo recursos do humor (ironia e sarcasmo), de modo que sua elocução soe como uma paródia de manchetes possíveis. 
Célula 4 - Pedagogisando-se:

A agente em cena faz sua apresentação declarando: "Meu nome é Nádia e eu sou professora de escola pública, atriz, escritora e caipira", resultando dessa consideração de identidade, funções e lugares, a percepção do indivíduo em suas dimensões micro e macro social.

Enquanto átomo-personagem, questiona os valores e estruturas do processo educacional, abordando o conhecimento de si como uma chave para o reconhecimento e reelaboração de sua formação humana em ordem política e estética, propósito expresso por meio de gestos harmonicamente sincronizados com a fala, em uma espécie de balé textual e corporalmente engajado.

Depois de se apresentar, Nádia se posiciona no fundo escuro, tomando fôlego - ação de disponibilização da atriz ao jogo de representação. Ela lê no livro "agradecemos a empresa educadora e evangelizadora que nos mostraram como único caminho possível para atingimento de plena felicidade, alegria e salvação, o conhecimento dos livros".

A seguir, rompendo essa instância criada, abre espaço para interlocução entre a atriz/professora e quem assiste, quando, ao fechar o livro, dirige-se para a câmera: "ao que acrescentamos o conhecimento de mim".

O som ambiente situa a cena em um cenário sonoro de multidão gritando palavras de ordem, como em uma manifestação.

Figura 7. Átomo-personagem 4, na luta pedagógica.

Fala 1a:

“[...] educador e aprendiz [...] levedura $[. .$.$] veias de cipós e seiva$ [...] do ser apreendido [...] terreno ancestral [...] heróis eternizados em estátuas [...] dedos rachados de pó e giz [...] desconfiança, o olhar bravio, indeciso [...] apanhando nos protestos, recebendo sprays de pimenta [...] não deixaremos de ver $[\ldots]^{\prime \prime} \cdot\left(2^{\prime} 10^{\prime \prime}\right)$

Nota: vídeo completo com duração de 7'56". Disponível em: https://www.youtube.com/watch?v=ayoGYMzaQLI\&t=1s .

De forma mais precisa, os termos utilizados na Fala 1a, contrapõe as funções sociais discutidas no cerne da formação humana, contextualizando tais funções, no texto, pela correlação contínua entre os termos "Educador" e "Aprendiz" com termos ou 
expressões adjacentes aos mesmos, salientando, em um primeiro momento, uma qualidade orgânica dessas posições - pelas expressões "levedura", "cipó" e "seiva" que têm como base de geração um "terreno ancestral", contraposto à imagem paralisante de "heróis eternizados em estátuas".

No tocante a isso, observa-se ainda que se as ações representativas dessas funções libertárias se coadunam pelo desgaste dos "dedos rachados de pó de giz" do educador, ou pela insegurança inocente do educando, balizada por um sentimento de "desconfiança, o olhar bravio, indeciso". Essa conjunção se dá pela ideia de um agente pautar o outro como desafios mútuos da conquista pedagógica.

Ainda que tal conquista pudesse ser advogada como manifestação de um poder do primeiro sobre o segundo, observa-se também, uma abertura dialógica entre o gesto cênico e a palavra, harmonizando ações em relação ao que se diz, tendo a mesma agente ocupando ambos os papeis citados.

Por fim, os termos que explicitam o teor político da encenação - como dito, salientado pelo ambiente sonoro de uma manifestação -, são denunciados pela presença dos resultantes tipicamente repressivos nessa ordem de enunciação coletiva "apanhando em protestos, recebendo sprays de pimenta nos olhos", ou seja, a luta diária por um espaço de conciliação entre a formação cidadã e o ambiente social repressivo, tendo como desafio permanente a resistência de todos os envolvidos na mudança para o que se ambiciona como melhor.

Célula 5 - Libertando-se:

A fala de apresentação da agente dessa cena é: "Meu nome é Ana Cristina e o meu lugar e minha função no mundo é sobreviver aqui”, deliberando, como prisma desse átomo-personagem, continuidade do teor essencial de sua proposição, ou seja, "sobreviver", atualizar seu viver no mundo, o que, na encenação, é construído pela elaboração da fala aliada ao dispositivo (imageticamente o plano de enquadramento da cena tenta produzir um efeito visual de "palanque".

Ana Cristina assume o lugar de sobrevivente, fazendo desse ato sua função exemplar para os que com ela se identificam. Ela debate o fenômeno do conhecimento como resultante de um processo dialógico, sempre em situação de confronto (amigável ou não) de um sujeito em relação ao outro sujeito da interação, sobretudo se cada um se constitua de mundos sociais diferentes entre si.

Todo o momento cênico é composto priorizando a manutenção de um efeito de discurso político direcionado a uma multidão. Em termos objetivos, interessa provocar a sensação de uma ativista voltada a temas e questionamentos circundantes ao embate entre indivíduo e indivíduo, indivíduo e sociedade, indivíduo e instituições/sistemas sociais. 
Figura 8. Átomo-personagem 5, no engajamento das frentes.

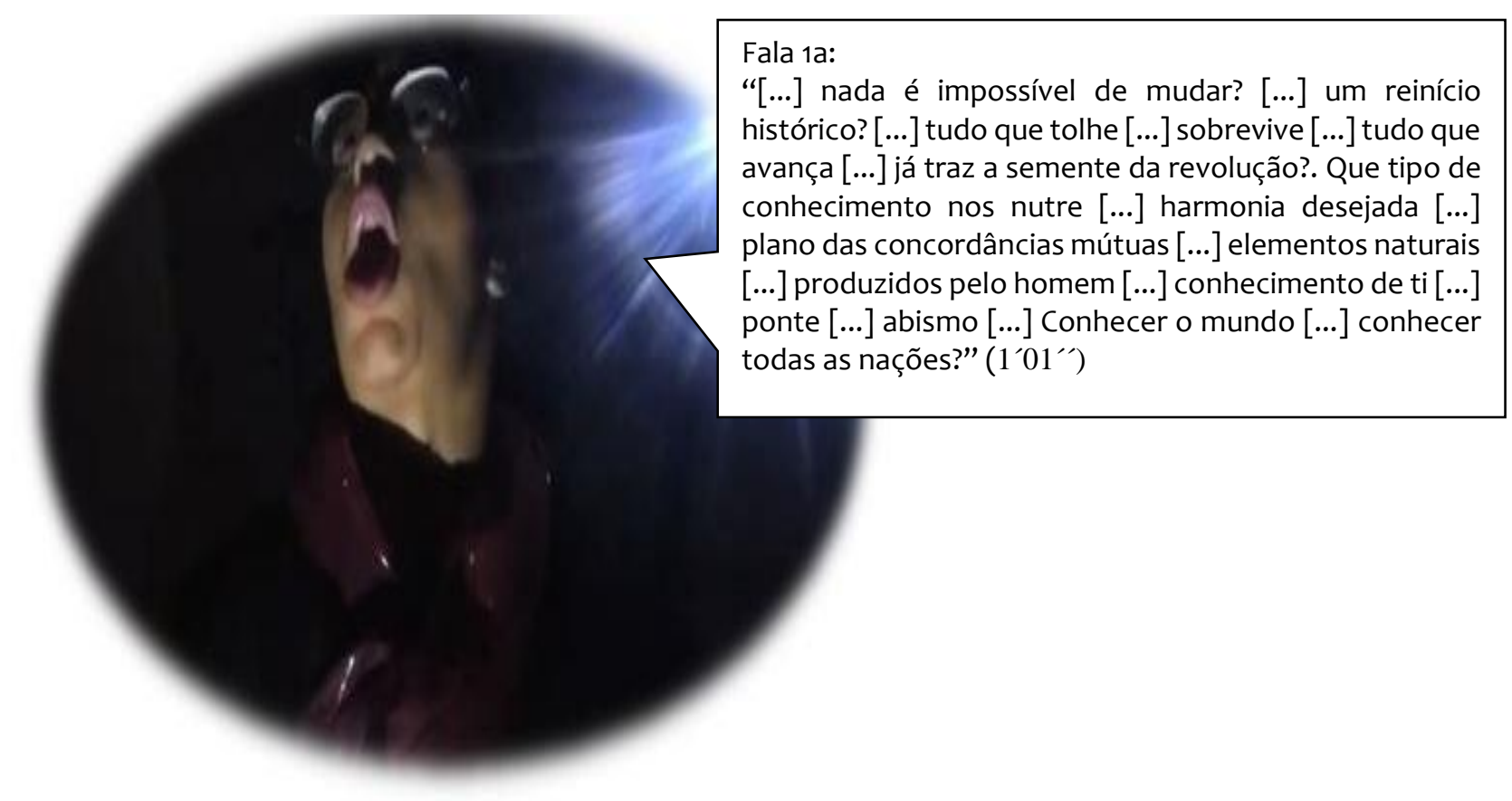

Nota: vídeo completo com duração de 8'04". Disponível em:

https://www.youtube.com/watch?v=VoDwColspUU

Os termos que salientam essa intenção se orientam ora pelo questionamento de mudança "nada é impossível de mudar?", vinculando-se a isso a noção de "um reinício histórico?" como resultante desse empenho/desempenho. Ana prossegue questionando forças controversas em "tudo que tolhe" e "sobrevive", "tudo que avança" e "já traz a semente da revolução?", induzindo-lhes qualificações potencialmente propulsoras de melhorias do entorno e do ser. Concebendo-se perguntar "Que tipo de conhecimento nos nutre" em prol de uma "harmonia desejada", debatendo-se um "plano das concordâncias mútuas" entre "elementos naturais" ou "produzidos pelo homem".

Por fim, a cisma central dessa fala finaliza a consideração de que se o "conhecimento de ti" forneceria um "conhecimento de mim", ou ainda, se os indivíduos seriam "ponte" "abismo", um do outro?

Nesse grau de complexidade, finaliza perguntando se "Conhecer o mundo" seria o mesmo que "conhecer todas as nações", ou seja, se seria possível reduzir termos e sentidos pela teoria de um mundo único, mas não pela práxis de uma constelação de culturas multifacetada. 
Célula 6 - Reencenando-se:

Roger Freire - ator, estudante de teatro, gerente-lojista - assume o átomopersonagem que reflete sobre as representações sociais dos indivíduos, suas máscaras e funções, desejos e frustrações de realização social, buscando entender uma dimensão de conhecimento presente. Sua apresentação assinala a condição libertária de ser e estar no mundo: “Meu nome é Roger, sou gay, sou livre e meu lugar é onde eu quiser".

A cena de Roger transcorre em um aparente camarim em que o ator-personagemagente, sob uma constante variação de luzes, proclama suas convicções.

Figura 9. Átomo-personagem 6, discutindo máscaras.

Fala 1a:

"[...] analiso os saberes decantarem [...] trajetória coletiva." ( $\left.55^{\prime \prime}\right)$
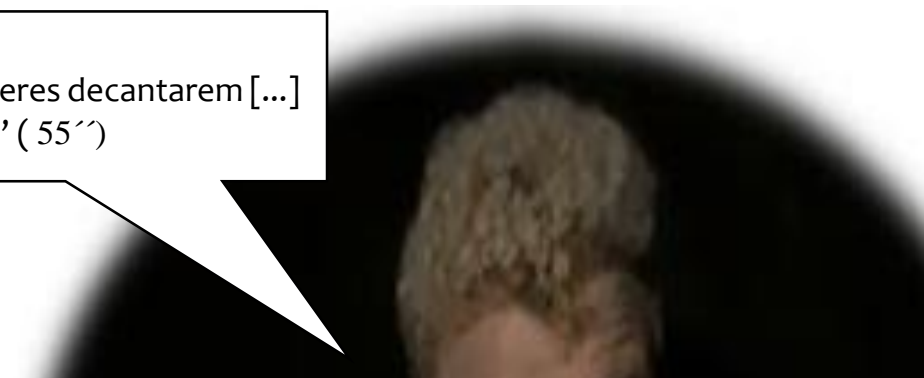

Fala 1b:

"Seríamos nós solitárias letras [...] fazem nascer palavras? [...] orações gravitacionalmente superiores a uma prece $[\ldots]$ narrativas-ser $[\ldots]$ se fariam em luzes [...] História ?". (1'45")

Nota: vídeo completo com duração de 7’43”. Disponível em:

https://www.youtube.com/watch?v=04/1Vwbdsjc .

Nesse sentido, a expressão "analiso os saberes decantarem", dita na Fala 1a enquanto se maquia e seguida pela observação de uma "trajetória coletiva", sintoniza seus dilemas e questionamentos reflexivos ao processo de desenvolvimento humano coletivo e não apenas individual. 
O jogo de uma representação social - similar ao de uma performance social - conforme sinalizado em Goffman, ganha nessa cena sua maior visibilidade.

Enfatiza-se, a partir dos elementos expressivos de articulação narrativa metafórica dispositivos imagéticos (o cenário induzido de um camarim ou um bastidor) e sonoros (o murmúrio típico de uma platéia) - a recondução a uma analogia do teatro como um símbolo de uma perspectiva antropológica, que se reflete na representação coletiva como insumo de uma construção da sociedade e de um conhecimento societário.

Questionamentos na ordem de "Seríamos nós solitárias letras", "orações gravitacionalmente superiores a uma prece", na Fala 1b, coadunam o interesse de busca crescente de desenvolvimento ritual por meio de "narrativas-ser" que "se fariam em luzes" e teceriam a "História". Ou seja, interpreta-se a jornada do agente pela condição de exploração do cotidiano como instrumento de progressão comunitária, quase religiosa, em seu sentido maior (religamento com o divino, com o cósmico).

Figura 10. Átomo-personagem 6 e seus reflexos.

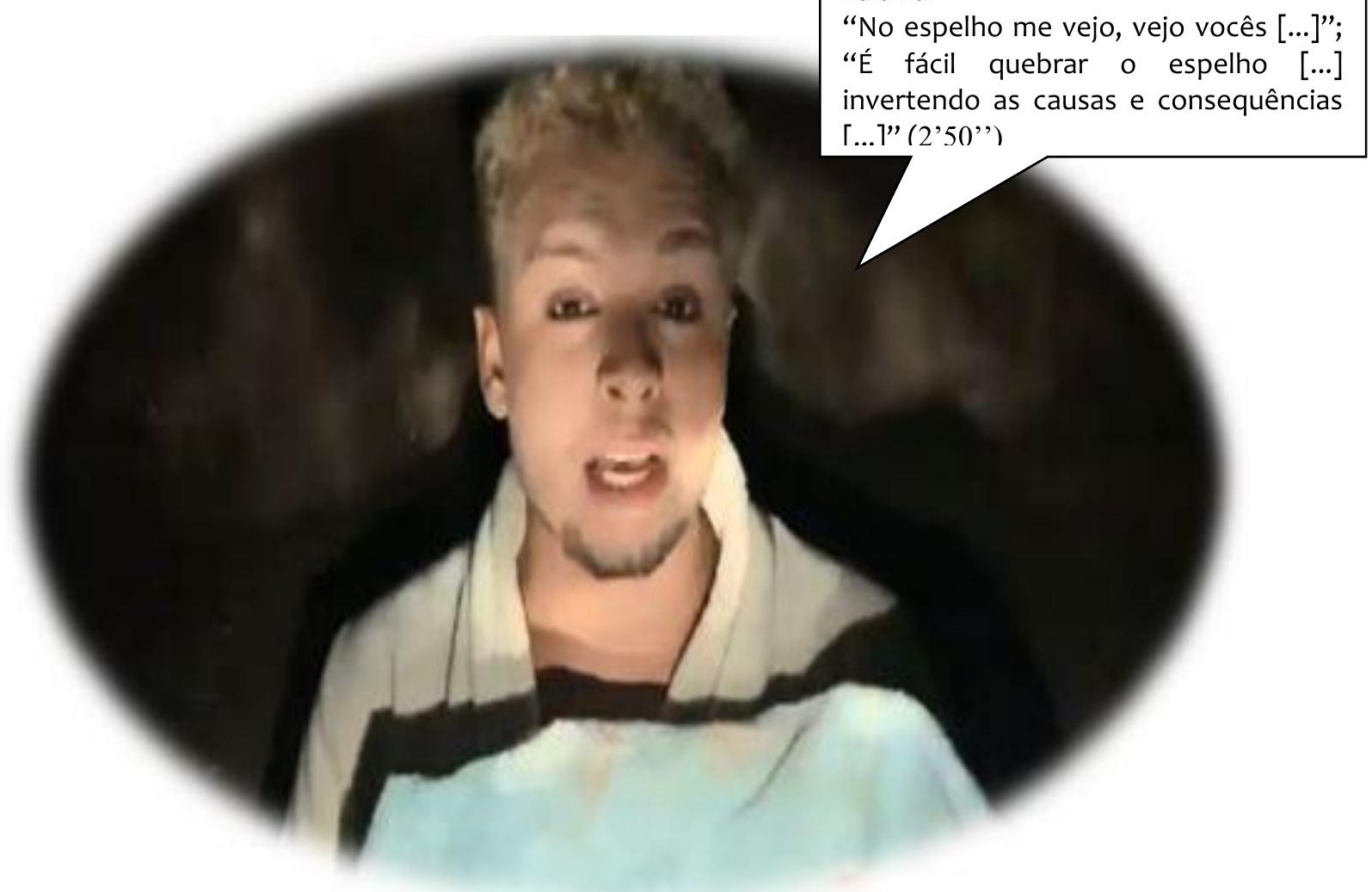

Nota: vídeo completo com duração de 7'43”. Disponível em:

https://www.youtube.com/watch?v=04/1VWbdsjc .

O símbolo do espelho reaparece de forma expressa pela conjunção de frases da Fala za como "No espelho me vejo, vejo vocês", "É fácil quebrar o espelho", "invertendo 
as causas e consequências", compondo um mosaico que recupera, ao longo do discurso, figuras heroicas ambivalentes (no sentido de ícones de uma rebeldia social em detrimento de uma submissão desumana) - são citados Martin Luther King e Malcon X.

Índices para a constatação de um paradoxo histórico - já que ambos os nomes recuperam uma dignidade avassaladora, em contraste com uma realidade social proporcionalmente devassa - que funciona como fundamento para uma ação de descoberta de si para enfrentamento de um esmagamento identitário, em nível comunitário (em larga escala).

Convém dizer que, ao usar-se a palavra "heróicas", tem-se em vista a contradição que tal qualificação traz, uma vez que pode favorecer uma perspectiva colonial quando serve à função de denotar uma exceção que confirma o discurso hegemônico comparando com a expressão "heróis eternizados em estátuas" - da célula 4, têm-se aqui a noção orgânica do humano e não estática da estátua -, ou seja, enquanto figuras históricas, tanto Martin Luther King quanto Malcon X apagam o superficialismo das pautas coletivas e geracionais que os gerou e atualizam o herói pela perspectiva humana, passível de equívocos e, portanto, não estática.

Célula 7 - Arqueologizando-se:

Daniele Buzatto - atriz, palhaça, artesã - representa o Átomo-personagem que busca emergir de uma visão antepassada, renovando-se pelo processo de revisão histórica do projeto civilizatório, projeto carente de um equilíbrio entre o processo de aprendizado e sua finalidade: o saber como ação a longo prazo.

Em sua apresentação se denomina, enquanto o enquadramento da cena focaliza uma vela em primeiro plano, com o fundo escuro: "um amontoado de ossos, carne, sangue e pele chamado Daniele. Meu lugar no mundo: aqui. Minha função no mundo: mostrar que o mundo não é só isso", conciliando uma noção de si - indivíduo - e de um coletivo maior, em âmbito amplificado ao de "mundo" social e objetivo, territorial e aparente, ou seja, temporalmente considerado: arqueológico.

Depois de apresentar-se e dizer suas primeiras palavras de proclamação, Daniele distancia a vela da câmera, aproximando seu rosto em planos de detalhe da boca e dos olhos, restituindo um enfoque biológico de quem fala, e vê, a longa narrativa que deslinda a série de violências dos sistemas de pensamento sobre o ser vivente.

Tudo é dito com um fundo sonoro lento, enfatizando o recato e a seriedade correspondentes à arqueologia proposta, e recuperada. 
Figura 11. Átomo-personagem 7 em seu jogo arqueológico.

Fala 1a:

"[...] dragões que guardo [...] desengano

$[\ldots]$ libertar-se [...] aprisionar-se $[\ldots]$ tentação $[. .$.$] resignada [. .$.$] oratórias que$ distorcem [...] nos afastam [...] retirar [...] dialogando de boa-fé [...] solitude do pensar [...] troca e parceria." (4'00")

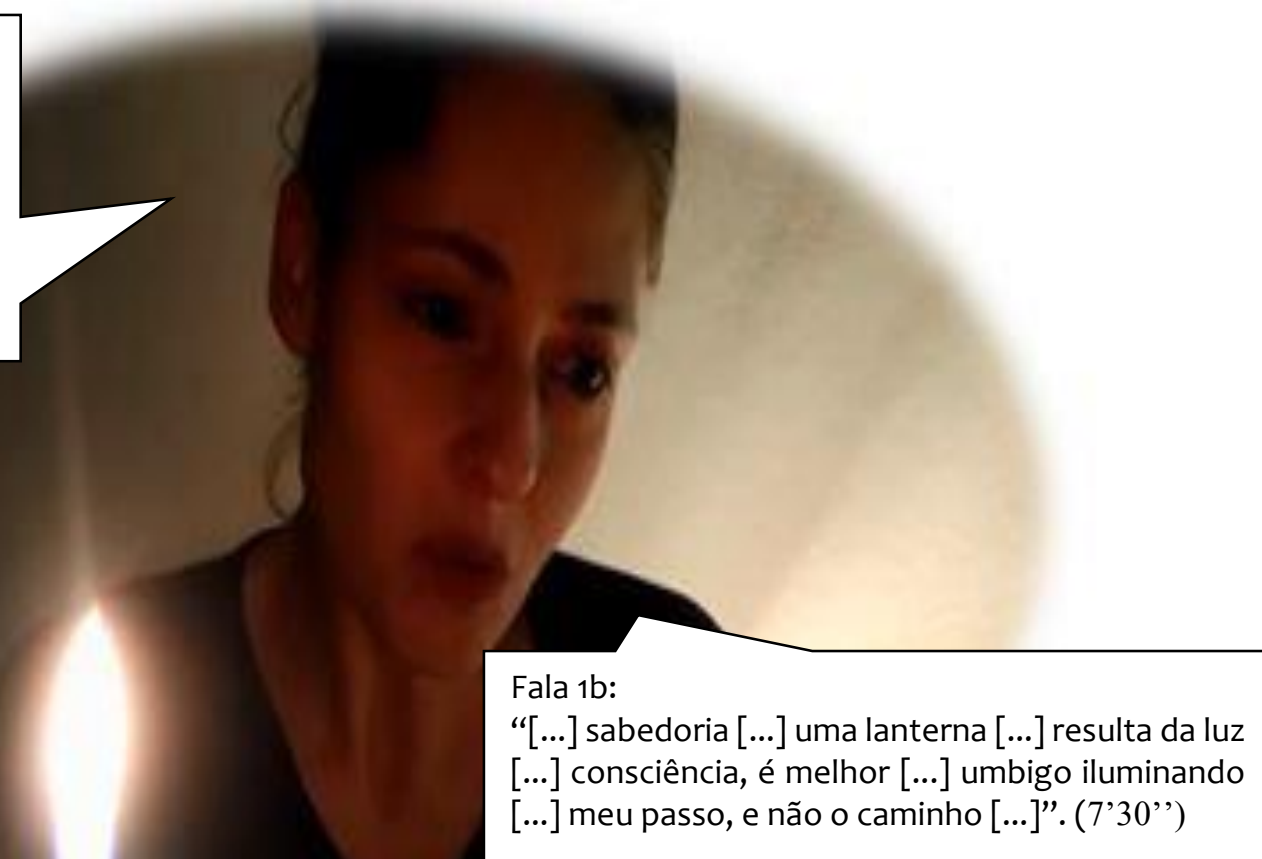

Nota: vídeo completo com duração de 11'31". Disponível em:

https://www.youtube.com/watch?v=cYWWz00651M\&t=1s .

Em termos discusivo-textuais, salienta-se na Fala 1a uma urgência metodológica nessa arqueologização linguística, conciliando imagens místicas, "dragões que guardo" a anseios de libertação - a cadeia de signos "desengano" "libertar-se" "aprisionar-se" "tentação", contraposta aos pedidos de que tais anseios não a tornassem "resignada" a "oratórias que distorcem", "nos afastam", solicitando a consciência de que ela saiba se "retirar", "dialogando de boa-fé", pelo ato de "descobrir o mundo" por uma "solitude do pensar", sem recair na perda de "troca e parceria".

Sua fala compõe uma conclamação à entrega de si a uma missão superior, pela qual ela busca harmonia.

A proclamante manterá uma relação de proximidade e distanciamento da câmera até o fim do vídeo, causando diferenças de iluminação (a vela está parada o tempo todo), e desenhos de sombras estabelecem (ainda que em outra estética) uma contraposição com os recursos utilizados na Célula 3, anteriormente descrita, em um jogo de revelação por meio da luz/sombra, semelhante ao processo de retirada de detritos realizada na escavação arqueológica. 
Por fim, na Fala 1b, Daniele opera uma fonte de luz ao fundo (lanterna), ressignificandoa pelo uso metafórico do termo, relacionando-a ao termo "sabedoria", explicando, por meio do uso subseqüente dos termos "uma lanterna”, "resulta da luz", "consciência, é melhor", "umbigo", "iluminando", "meu passo, e não o caminho", a necessidade de cautela na absorção do ego de uma sabedoria sempre relativa, administrada pela reflexão contínua não só dos anseios, mas também dos processos de escolha no caminho da evolução.

\section{Célula 8 - Redesdobrando-se:}

O último átomo antes do retorno da Criatura é representado pela atriz Daniela Soledade, que se apresenta assim: "Eu sou Daniela, filha da Maria de Lurdes do Saturnino, neta da Rosa Maria e do José Vicente. Eu sou artista”, um redesdobramento de si mesma em meio aos referentes próprios de uma ancestralidade presente em seu ser e seu estar no mundo (descendência, profissão de fé).

Nessa célula, sua performance busca representar o desdobramento do humano em uma dimensão cósmica, observando além dos laços da matéria, mirando-se na convergência entre homem e uma pretensa sabedoria eterna.

Enquanto dispositivo, assume-se a câmera como objeto a ser manipulado pela própria Daniela, que a move pelo espaço, com enquadramentos em que o fundo configura um ambiente vago, com luzes que lembram estrelas. Na composição sonora da cena, ouvese, ao fundo, o vento, enfatizando o sentido de vazio (não vácuo) do espaço.

Em contrapartida, o som ambiente da casa da própria atriz (galo cantando) repercute a ideia de uma memória pessoal atravessando toda a retórica etérea que ela proclama - esse tema da memória reaparece pelo uso metafórico de uma voz interna que se sobrepõe a voz "presencial” (em tempo real) na cena.

O tom aveludado, lento, com que se expressa fortalecem um estado de sonolência e relaxamento que contrapõe ações de dormência (Dormir) e vigília (acordar).

Na Fala 1a, os termos considerados mais relevantes para a cena têm, em sua primeira ordenação, a ideia do dispersar-se diante do infinito (que simbolicamente condiciona a noção tecnológica pelo uso de dispositivos eletrônicos para sobreposição da fala gravada à fala dita em cena), assim "verdade onipresente do vácuo", "ramalhete de átomos, de almas...", e "sendo, ao mesmo tempo, o todo, o nada, o tudo.", contrapõem efeitos contrastantes do diluir-se e integrar-se continuamente. 
Figura 12. Átomo-personagem 8, a caminho da recomposição.

Fala 1a:

“[...] verdade onipresente do vácuo [...] ramalhete de átomos, de almas [...] sendo, ao mesmo tempo, o todo, o nada, o tudo [...] iluminada, apaziguada, a criatura apenas é [...] atirado em meio ao infinito [...] nem grande, nem pequeno são antônimos." $\left(4^{\prime} 25^{\prime \prime}\right)$

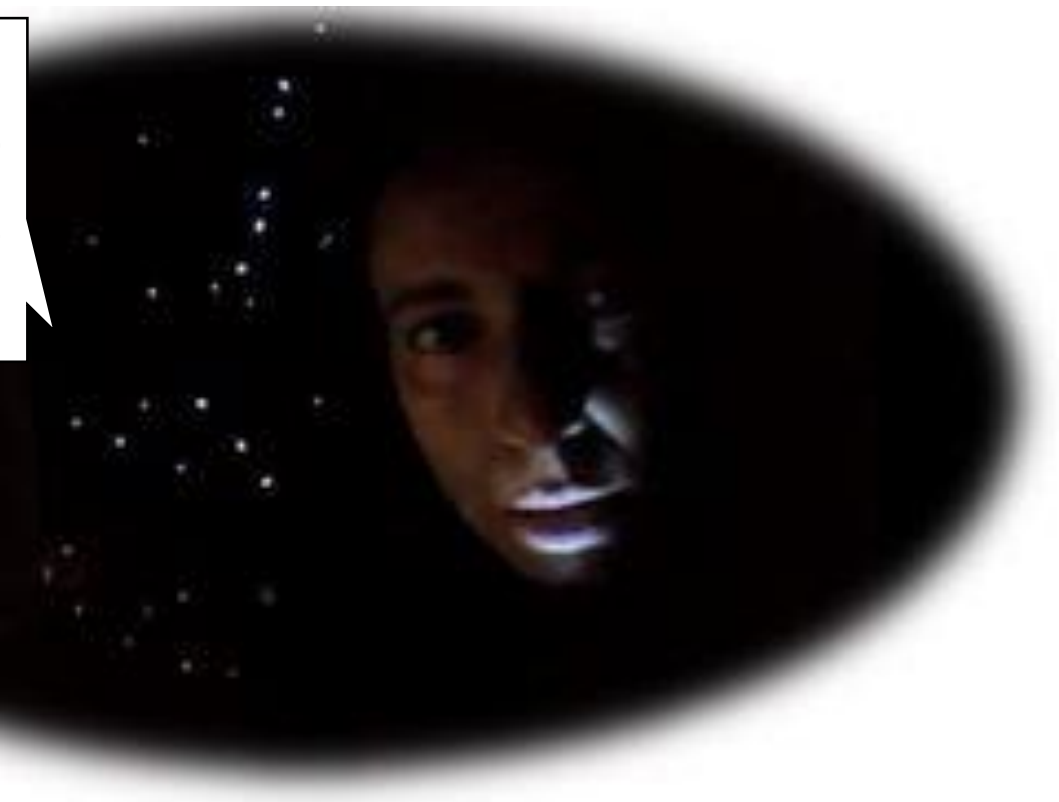

Nota: vídeo completo com duração de 11'44". Disponível em:

https://www.youtube.com/watch?v=eWzJGEEGYbU\&t=5s .

O sentimento de paz é fortalecido pelas expressões que delimitam um estado particular de reencontro do ser consigo mesmo "iluminada, apaziguada, a criatura apenas é”, para depois conjugar essa "religação" com sensações de perda de si mesma em "atirado em meio ao infinito", e perda de noções concretas sobre a experiência em "nem grande, nem pequeno são antônimos.".

O ambiente ainda traz, em seus minutos finais, o uso de uma aclimação cenográfica (promovida pelo aparecimento de fumaças de incenso) que tenderá a criar um elo entre o que se é e o que ser propõe a se tornar a partir dessa abstração do tempo e do espaço - lembrando que a criatura da Célula o retornará na subsequente (Célula 9), finalizando sua jornada de busca de respostas sobre suas cismas.

\section{À GUISA DE ENCERRAMENTO}

A ideia dessa seção é apenas apontar o interesse de finalização do processo de busca da Criatura, contemplada pela reintegração da mesma entre seus átomos e sua voz da consciência, presentificada nas articulações de Paulo Borges, orador que dialoga com os proclamantes no final de cada célula. 


\section{Finalização}

A cena final funciona como epílogo da travessia proposta pelo projeto. Nela se integram todas as discussões e "contágios" do ser pelos seus átomos antecessores. Também retoma algumas considerações, sem, no entanto, delimitar conclusões - a proposta é aberta, por isso, enquanto trabalho descritivo, esse texto finalizará seu relato, por coerência, pela argumentação contida nessa última subseção, buscando estimular o leitor a ele mesmo consolidar suas impressões pela experiência de acesso aos vídeos pelos links disponibilizados ao longo do relato.

Célula 9 - Revolucionando-se.

O ator Marco Madeira retorna com sua personagem a Criatura. Como antecipado na cena anterior, a fumaça é o elemento de ligação entre a personagem e o átomo anterior. Prefigura-se, nessa retomada, uma sinalização de término da trajetória em que o ato de revolucionar-se é a única chance possível de conciliação das cismas vivenciadas.

Figura 13. A Criatura em processo de religação.

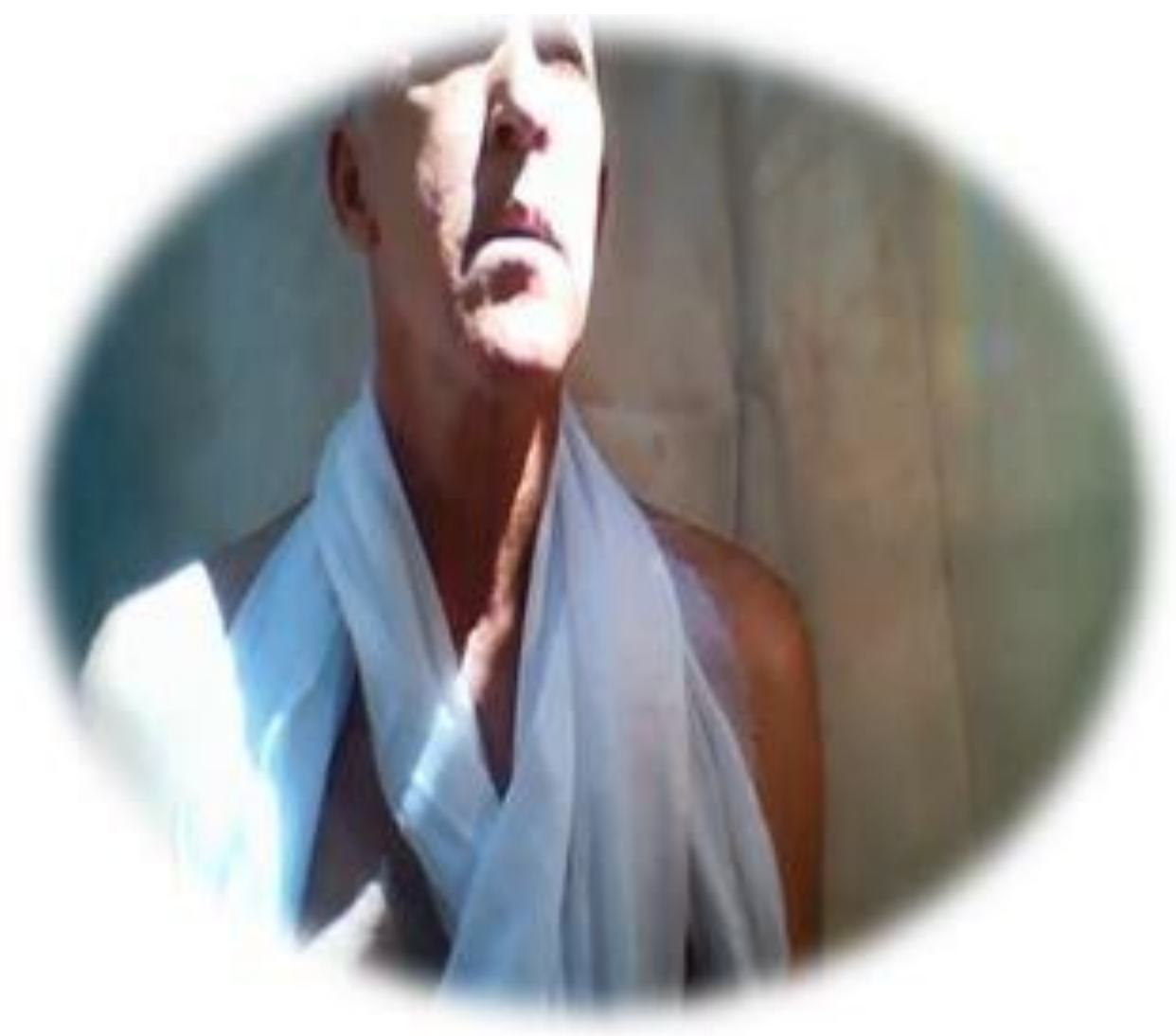

Nota: vídeo completo com duração de 11'20". Disponível em: https://www.youtube.com/watch?v=XWN6r7WVru\&t=62s. 
O que mais se enfatiza nessa célula não é a presença do ator, mas a imagem estática do ator Paulo Borges (foto apresentada inicialmente na Célula 1) que interpreta o recitador (a voz da consciência predominante no final de todas as células) por meio do qual todos interpretes repercutem a vivência atômica.

Figura 14. A voz da consciência na finalização da obra.

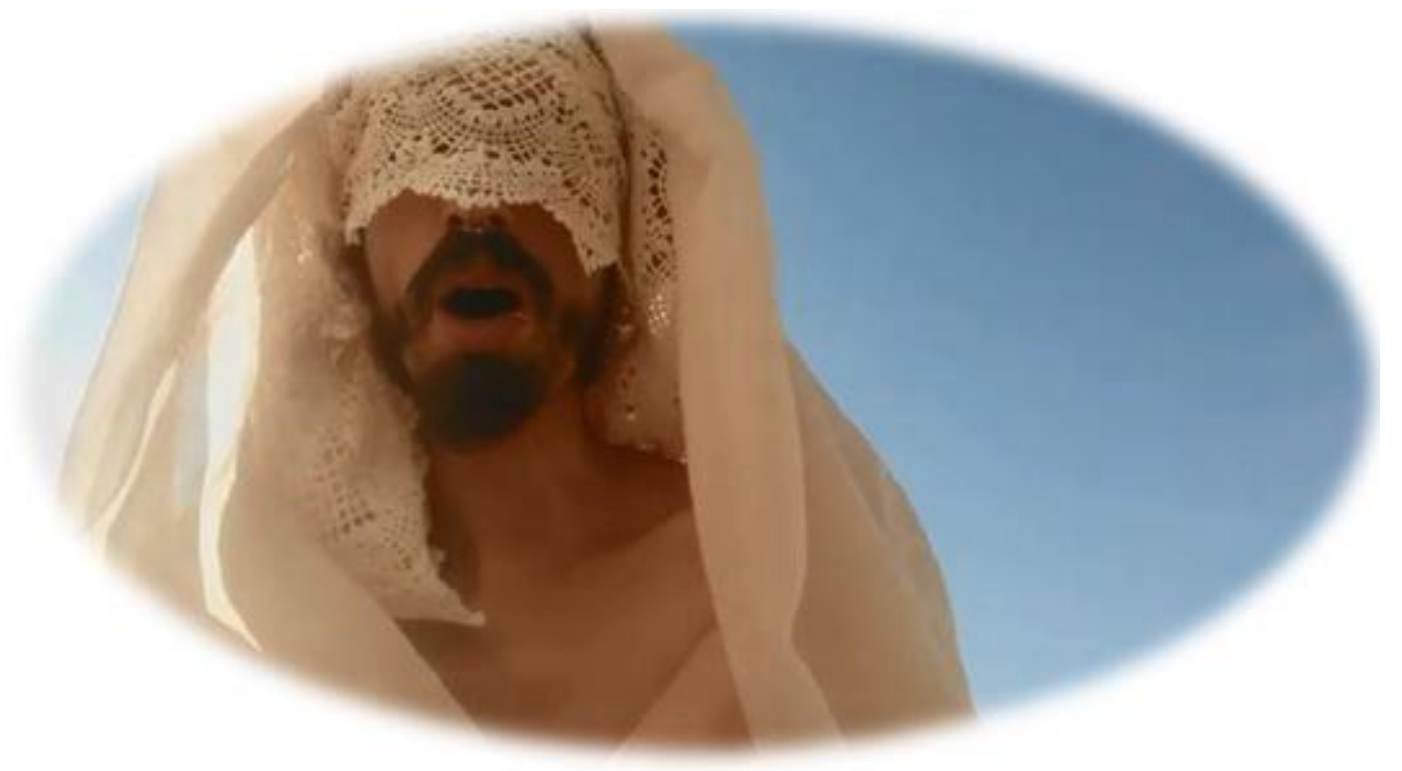

Nota: vídeo completo com duração de 11'20". Disponível em:

https://www.youtube.com/watch?v=XW-N6r7WVrU\&t=62s .

Essas fotografias de Paulo são constantemente contrapostas à imagem em movimento de Marco, suas vozes, por vezes, são sobrepostas em dimensões tríades (ora voz de Marco sobre voz de Paulo, ora voz de Marco sobre a própria voz).

Dessa forma, salienta-se no vídeo a ordenação de pontos que deliberam essas convergências e sobreposições, ora em caráter de replicante a uma segunda esfera de consciência, ora em caráter de solilóquio.

O cântico entoado por Paulo é usado como uma espécie de oração por Marco e isso já empresta uma organização semelhante do sagrado em forma de devoção musicada. Não se argumentará quais os predicados da cena, apenas se enfatizará seu caráter terminal em que o discurso gera a expressão sem se explicar, ou fundamentar-se em ordem teórica - todas as células precedentes já o fizeram.

Busca-se, nessa cena, apenas proporcionar um desejo de catarse, mas, contraditória e precocemente aniquilá-lo, uma vez que a manipulação evidente de cada enquadramento já demonstra o ato de condução do expectador, ou seja, a atenção 
racional não deve ser sobrepujada pela emoção irracional. Não se propõe solução fácil, mas sim, raciocínio, lucidez, responsabilidade diante do que se ouve, oferta-se a chance de contrariar a expectativa de uma emotividade cega e, portanto, nas condições do projeto proposto, ineficaz.

Dessa forma, finaliza-se a sequência dos vídeos produzidos com a lista de colaboradores do projeto, suas funções e contribuições, da mesma forma que finalizamos essa relatoria pela disponibilização de links do trabalho realizado, assim como das obras inspiradoras de nossa humilde produção.

\section{OBRAS INSPIRADORAS E REFERÊNCIAS DE ACESSO}

CÉLULAS Cênicas. Célula Cênica, 2021. Direção: Marco Madeira; Nádia Stevanato. Produção: Colaborativa. São Carlos: 2019. Disponível em: https://www.youtube.com/results? search_query=c\%C3\%Aglula+c\%C3\%AAnica .

GOFFMAN, Irving. A representação do eu na vida cotidiana. Petrópolis: Editora Vozes, 2002.

I HAVE a dream speech: Dr. Martin Luther King, Jr. Inglês Essencial. 2017. Disponível em: https://www.inglesessencial.com/blog/2017/3/12/mlkspeech

KAFKA, Franz. Prometheus. In: KAFKA, Franz. The great wall of China: and other pieces. London: Secker and Warburg, 1946. p. 128 (pdf). Disponível em:

https://archive.org/details/in.ernet.dli.2015.184806/page/n1/mode/2up

MOHANDAS Gandhi's letter to Adolf Hitler, 1939. The Guardian. The Observer. 2013. Disponível em:

https://www.theguardian.com/culture/interactive/2013/oct/12/mohandas-gandhiadolf-hitler-letter

MONÓLOGO do vírus. N-1edições. 2020. Disponível em: https://n-1edicoes.org/005

MORAES, Alana. Atravessar como Medusas as coordenadas dos heróis. N-1edições. 2020. Disponível em: https://n-1edicoes.org/032

SANTEIRO, Sérgio. Conceito de dramaturgia natural. Revista Filme Cultura, n. 30, p. 80-85, ago. 1978.

SHELLEY, Mary. capítulo 5. In: SHELLEY, M. Frankenstein or the modern Prometheus. London: Colburn and Bentley, 1831. p. 43. Disponível em:

https://ia802307.us.archive.org/34/items/ghostseer01schiuoft/ghostseer01schiuoft_b w.pdf

SÓFOCLES. Cena 1. In: SÓFOCLES. Rei Édipo. Domínio Público. 200[?]. Disponível em: http://www.dominiopublico.gov.br/download/texto/cv000024.pdf.p. 2. 